\title{
Prevalence and risk factors associated with the occurrence of musculoskeletal pain in socio-educational agents
}

\author{
Prevalência e fatores associados à ocorrência de dor musculoesquelética em agentes \\ socioeducadores
}

Patrícia Bittencourt Toscani Greco ${ }^{1}$, Tânia Solange Bosi de Souza Magnago ${ }^{1}$, Emanuelli Mancio Ferreira da Luz ${ }^{1}$, Juliana Dal Ongaro ${ }^{1}$, Bruna Pereira Chagas ${ }^{1}$, Angela Isabel dos Santos Dullius ${ }^{1}$

Objective: to verify the prevalence and associated factors of musculoskeletal pain in socio-educational agents. Methods: cross-sectional study with 381 socio-educational agents using a form addressing issues related to socio-demographic profile, work, habits and health, as well as musculoskeletal pain assessment. Data were analyzed using descriptive and analytical statistics, with a significance level of $5 \%$. Results: socio-educational agents were predominantly female $(55.8 \%)$ with mean age of 44.4 years $( \pm 8.17)$. The mean pain intensity score was 5.03 ( \pm 3.12 ); $43.0 \%$ participants reported low/moderate pain, and 39.9\%, strong/unbearable pain. Conclusion: the prevalence of musculoskeletal pain was $82.9 \%$. The associated factors were work leave of up to 24 days, psychological counseling and less than 8 daily sleeping hours.

Descriptors: Work; Occupational Health; Working Conditions; Musculoskeletal Pain.

Objetivo: verificar a prevalência e os fatores associados à ocorrência de dor musculoesquelética em agentes socioeducadores. Métodos: estudo transversal, com 381 agentes socioeducadores, utilizando-se formulário contendo dados sociodemográficos e laborais, sobre os hábitos e a saúde, além de avaliação de dor musculoesquelética. Os dados foram analisados por estatística descritiva e analítica, com níveis de significância de $5 \%$. Resultados: os agentes socioeducadores são predominantemente do sexo feminino $(55,8 \%)$ e com idade média de 44,4 anos $( \pm 8,17)$. A pontuação média de intensidade de dor foi de 5,03 $( \pm 3,12) ; 43,0 \%$ relataram dor fraca/moderada e 39,9\% com dor forte/insuportável. Conclusão: a prevalência de dor musculoesquelética foi de $82,9 \%$. Os fatores associados foram estar afastado do trabalho até 24 dias, estar em acompanhamento psicológico e ter menos de 8 horas diárias de sono.

Descritores: Trabalho; Saúde do Trabalhador; Condições de Trabalho; Dor Musculoesquelética.

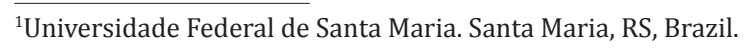




\section{Introduction}

The work process in Socio-Educational Service Centers aims at the implementation of educational measures under internment and semi-confinement of juvenile offenders and is bound to and regulated by the Socio-Educational Service Foundation. The foundation is guided by the Program of Application of Socio-Educational Measures in Internment and Semi-confinement. The program has the basic objective of guaranteeing individual and collective rights of adolescents, according to the pedagogical and therapeutic aspects $^{(1)}$.

Socio-educational agents in Socio-Educational Service Centers are responsible for ensuring the implementation of the Program of Application of Socio-Educational Measures in Internment and Semi-confinement, for the security of inmates and for implementing planned actions in the Individual Adolescent Plan. As these instructions spend continuous 24 hours in contact with the adolescents, they also conduct guidelines, providing opportunities for the development of bonds ${ }^{(1)}$, what makes them as co-responsible for the rehabilitation process and a reference for the institutionalized adolescents.

But, even with these responsibilities, they experience difficulties in the exercise of their professional activities. Among them are the misunderstanding of the principles of the Children and Adolescent Statute by the teams; deficient courses and lack of regular training; insufficient number of workers; and the lack of material ${ }^{(2)}$. These gaps cause difficulty to fulfill functions and overloading tasks.

The activities of socio-educational agents include inspection, accompanying the adolescents in activities, physical restraint when necessary and constant vigilance, mainly because of the risk of detainees transforming materials into weapons ${ }^{(3)}$. These activities require the application of force, especially with hands, as well as awkward postures, repetitive movements and stress related to psychosocial conditions in which the work takes place, propitiating musculoske- letal pain in the agents ${ }^{(4)}$.

The onset of musculoskeletal pain/disorders is linked to exposure to risks, as well as to the intensity, frequency and duration of exposure, besides the worker's ability to meet the demand ${ }^{(4)}$. Considering the characteristics of work activities performed by this class of workers, the aim of this study was to determine the prevalence and the factors associated with musculoskeletal pain in socio-educational agents.

\section{Methods}

Cross-sectional study performed with socio-educational agents from Socio-Educational Service Centers of the State of Rio Grande do Sul located in the capital city, Porto Alegre, Brazil (six units), and in the countryside of the state (seven units distributed in seven municipalities).

The study population consisted of 819 socio-educational agents of Socio-Educational Service Centers of Rio Grande do Sul distributed as follows: 486 belonging to the city of Porto Alegre and 333 to the countryside. The sample consisted of 381 socio-educational agents, considering sampling error of 3.68\%, estimated proportion of $50.0 \%$ and significance level of $5 \%$. The sample was selected by simple random draw of Socio-Educational Service Centers.

The study included socio-educational agents of both genders assigned to Socio-Educational Service Centers/RS, Brazil. For those who were returning from vacation or any other leave, the inclusion in the study happened only 30 days after their return to work. The study excluded agents who were on leave for health treatment, suspension and expulsion.

Data collection was conducted from March to August 2011 by the researcher and five official research assistants. Agents of Socio-Educational Service Centers were drawn in advance and invited to participate. Recruitment was carried out individually in the workplace. After the acceptance to take part in the study, the questionnaire was handed for completion by the worker. These were later collected by the rese- 
archer or by the assistants.

The questionnaire was self-applied and addressed issues related to socio-demographic profile and work, habits and health, and had one question on musculoskeletal pain. For the latter, an adapted scale was used(5). This scale considered presence of musculoskeletal pain cases where the respondent affirmatively answered the question "Did you feel pain or discomfort in the last seven days in any of these areas: neck, shoulders, upper back, hips and legs?" The answer was rated on a numerical scale from zero to 10 , where zero corresponds to no pain and 10 to the most intense pain ever felt ${ }^{(5)}$. For analysis, the intensity of pain was classified as: absent (zero), low or moderate (1-6) and from strong to unbearable (7-10). The instrument Cut down, Annoyed, Guilty, Eye-opener $(\mathrm{CAGE})^{(6)}$ was used to evaluate the suspicion of alcoholism, included as variable in lifestyle.

For the insertion of data, the Epi-Info ${ }^{\text {tw }}$ program version 6.4 was used, with independent double typing. After checking errors and inconsistencies, data analysis was carried out in the Predictive Analytics Software (PASW Statistics) from Statistical Package for Social Science, version 18.0 for Windows.

A descriptive analysis of socio-demographic profile, work characteristics, habits and health of workers was made. Subsequently, a bivariate analysis was performed. For this, the significance level of 5\% was adopted and the chi-squared test or Fisher's exact test was used to verify associations. A binomial test was used to specify the differences in proportions.

A univariate analysis was used to check gross associations between prevalence of musculoskeletal disorders and each of the categories of explanatory variables (socio-demographic, work, habits and health). Variables with $\mathrm{p}$ value $\leqq 0.110$ were included the multivariate analysis, but only factors associated with the level of $\mathrm{p}<0.05$ remained in the Final Model.

Multivariate analysis was calculated by binary logistic regression, by the method Enter. The following were potential confounding factors: gender, age, number of children, work shift, work schedule, days off, physical activity, medication, need for medical care, psychological counseling, sleep and suspicion for alcoholism. Logistic regression models were run with all these variables. Model 1 involved the socio-demographic variables (gender, age and number of children); Model 2 examined the work-related variables (shift, scale and absence from work); Model 3 involved the habits and health variables (physical activity, use of medication, need for medical care, psychological counseling, daily sleeping hours and suspicion for alcoholism). In the Final Model, variables were simultaneously analyzed: number of children, scale and leave from work, counseling and sleeping hours.

To each model analysed, variables were taken away when the $p$-value was above $11.0 \%(p \geq 0.110)$, and only the variables with $\mathrm{p}<0.05$ were kept. The magnitude of association between variables was estimated by calculating the odds ratios (OR) and their respective 95\% confidence intervals (95\%). The Hosmer-Lemeshow test was used to verify the fitness of the regression models. In this test, values may range from zero to 1 , and the closer to 1 , the better the fitness of the model.

The study complied with the formal requirements contained in the national and international regulatory standards for research involving human beings.

\section{Results}

A total of 381 socio-educational agents participated in the study, with prevalence of women (55.8\%), mean age of 44.4 years $( \pm 8.17)$, self-reported ${ }^{(7)}$ white-skinned $(75.3 \%)$, married or with a partner (64.4\%) and with two children (62.4\%). It was found that $54.3 \%$ of the subjects had undergraduate and postgraduate training, representing higher levels than high school, which was the prerequisite for the job.

As for working characteristics, a higher percentage of agents worked in the day shift (50.7\%), with experience of up to 10 years in Socio-Educational Service Centers, with a workload of up to 40 hours per 
week (67.5\%). An important finding was that $80.3 \%$ participants reported dissatisfaction with the number of workers in the working schedule.

As for life and health habits, $58.2 \%$ respondents had never used tobacco, $10.7 \%$ were suspected for alcoholism, according to $\operatorname{CAGE}^{(6)}$, and the mean daily sleeping time was 6.6 hours. Yet, $67.2 \%$ of agents did not practice regular physical activity, $50.3 \%$ spend only eventual occasions with leisure, $62.8 \%$ make use of medicines, being antihypertensive, antidepressants and anxiolytics the most used.

About reports of musculoskeletal pain, a mean pain intensity of $5.03( \pm 3.12)$ was observed. Of the 381 agents, $43.0 \%(n=164)$ reported low/moderate pain, 39.9\% ( $\mathrm{n}=152)$, strong/unbearable pain and $17.1 \%(n=65)$ did not report musculoskeletal pain. This means that a total of $82.9 \%(n=316)$ of agents presented some degree of pain in the seven days prior to data collection.

Table 1 - Distribution of socio-educational agents according to reports of musculoskeletal pain and socio-demographic variables. $(n=381)$

\begin{tabular}{|c|c|c|c|c|}
\hline \multirow{3}{*}{ Socio-demographic variables } & \multicolumn{3}{|c|}{ Musculoskeletal pain } & \multirow{3}{*}{$\mathbf{p}$} \\
\hline & \multirow{2}{*}{$\begin{array}{c}\text { Absent } \\
\mathbf{n}(\%)\end{array}$} & \multirow{2}{*}{$\begin{array}{c}\begin{array}{c}\text { Low/ } \\
\text { Moderate }\end{array} \\
\mathbf{n}(\%) \\
\end{array}$} & $\begin{array}{c}\text { Strong/ } \\
\text { Unbearable }\end{array}$ & \\
\hline & & & $n(\%)$ & \\
\hline \multicolumn{5}{|l|}{ Gender } \\
\hline Male & $32(19.0)$ & $88(52.4)$ & $48(28.6)$ & $0.001^{1}$ \\
\hline Female & $33(15.6)$ & $75(35.4)$ & $104(49.1)$ & \\
\hline Age (years) & & & & $0.060^{1}$ \\
\hline $27-40$ & $18(15.3)$ & $63(53.4)$ & $37(31.4)$ & \\
\hline $41-47$ & $17(14.4)$ & $46(39.0)$ & $55(46.6)$ & \\
\hline$>48$ & $27(19.9)$ & $52(38.2)$ & $57(41.9)$ & \\
\hline Marital situation & & & & $0.127^{1}$ \\
\hline Married/Partner & $36(14.8)$ & $112(45.9)$ & $96(39.3)$ & \\
\hline Single/No companion & $14(20.3)$ & $31(44.9)$ & $24(34.8)$ & \\
\hline $\begin{array}{l}\text { Widow }(\text { er }) / \text { separated } / \text { di- } \\
\text { vorced }\end{array}$ & $-15(22.7)$ & $20(30.3)$ & $31(47.0)$ & \\
\hline Number of children & & & & $0.107^{1}$ \\
\hline None & $9(11.8)$ & $39(51.3)$ & $28(36.8)$ & \\
\hline 1 & $29(23.8)$ & $51(41.8)$ & $42(34.4)$ & \\
\hline 2 & $14(12.2)$ & $48(41.7)$ & $53(46.1)$ & \\
\hline 3 & $13(19.4)$ & $25(37.3)$ & $29(43.3)$ & \\
\hline Schooling & & & & $0.502^{2}$ \\
\hline High school & $32(19.3)$ & $72(43.4)$ & $62(37.3)$ & \\
\hline Undergraduate Degree & $25(16.1)$ & $63(40.6)$ & $67(43.2)$ & \\
\hline Postgraduate Degree & $4(9.5)$ & $21(50.0)$ & $17(40.5)$ & \\
\hline
\end{tabular}

As shown in table 1 , there was association with gender according to the chi-square test, and the binomial test showed difference between male and female agents in relation to strong/unbearable pain. The proportion of women with strong pain was significantly higher than that men with strong pain. The other variables did not present statistically significant differences between the groups.

Table 2 - Distribution of socio-educational agents according to reports of musculoskeletal pain and work-related variables. $(n=381)$

\begin{tabular}{|c|c|c|c|c|}
\hline \multirow{3}{*}{ Work variables } & \multicolumn{3}{|c|}{ Musculoskeletal pain } & \multirow{3}{*}{$\mathbf{p}$} \\
\hline & Absent & $\begin{array}{c}\text { Low/ } \\
\text { Moderate }\end{array}$ & $\begin{array}{c}\text { Strong/ } \\
\text { Unbearable }\end{array}$ & \\
\hline & $n(\%)$ & $n(\%)$ & $n(\%)$ & \\
\hline \multicolumn{2}{|l|}{ Work shift } & & & $0.009^{1}$ \\
\hline Day & $26(13.5)$ & $76(39.4)$ & $91(47.2)$ & \\
\hline Night & $39(20.7)$ & $88(46.8)$ & $61(32.4)$ & \\
\hline \multicolumn{2}{|l|}{ Work schedule } & & & $0.032^{1}$ \\
\hline Enough & $19(26.4)$ & $32(44.4)$ & $21(29.2)$ & \\
\hline Insufficient & $44(15.0)$ & $126(42.9)$ & $124(42.2)$ & \\
\hline \multicolumn{2}{|l|}{ Other employment } & & & $0.560^{1}$ \\
\hline No & $58(16.8)$ & $147(42.5)$ & $141(40.8)$ & \\
\hline Yes & $7(20.0)$ & $17(48.6)$ & $11(31.4)$ & \\
\hline \multicolumn{2}{|l|}{ Days of leave } & & & $0.001^{2}$ \\
\hline None & $31(25.8)$ & $58(48.3)$ & $31(25.8)$ & \\
\hline$\leq 9$ & $18(13.3)$ & $60(44.4)$ & $57(42.2)$ & \\
\hline $10-24$ & $4(6.5)$ & $26(41.9)$ & $32(51.6)$ & \\
\hline $25-99$ & $2(6.3)$ & $12(37.5)$ & $18(56.3)$ & \\
\hline $100-365$ & $4(16.0)$ & $7(28.0)$ & $14(56.0)$ & \\
\hline \multicolumn{3}{|c|}{ Experience in the institution (years) } & & $0.895^{1}$ \\
\hline$\leq 10$ & $35(16.7)$ & $89(42.4)$ & $86(41.0)$ & \\
\hline$>10$ & $30(17.5)$ & $75(43.9)$ & $66(38.6)$ & \\
\hline \multicolumn{3}{|c|}{ Experience working as agent (years) } & & $0.470^{1}$ \\
\hline$\leq 12$ & $42(15.6)$ & $119(44.1)$ & $109(40.4)$ & \\
\hline$>12$ & $23(20.7)$ & $45(40.5)$ & $43(38.7)$ & \\
\hline
\end{tabular}

Table 2 shows that agents working on the day shift, agents who considered the amount workers in the schedule insufficient, and who required between 25 and 99 days off from work, presented higher percentage of strong/unbearable musculoskeletal pain (47.2\%, $42.2 \%$ and $56.3 \%$, respectively). 
Table 3 - Distribution of socio-educational agents according to reports of musculoskeletal pain and habits and health variables. $(\mathrm{n}=381)$

\begin{tabular}{|c|c|c|c|c|}
\hline \multirow{3}{*}{$\begin{array}{l}\text { Habits and health varia- } \\
\text { bles }\end{array}$} & \multicolumn{3}{|c|}{ Musculoskeletal pain } & \multirow{3}{*}{$\mathbf{p}^{1}$} \\
\hline & Absent & $\begin{array}{c}\text { Low/ } \\
\text { Moderate }\end{array}$ & $\begin{array}{c}\text { Strong/ } \\
\text { Unbearable }\end{array}$ & \\
\hline & n(\%) & n(\%) & n(\%) & \\
\hline Physical activity & & & & 0.001 \\
\hline No & $35(13.7)$ & 101(39.5) & $120(46.9)$ & \\
\hline Yes & $30(24.0)$ & $63(50.4)$ & $32(25.6)$ & \\
\hline Smoking & & & & 0.957 \\
\hline I never smoked & $39(17.7)$ & $94(42.7)$ & $87(39.5)$ & \\
\hline I smoked, but stopped & $12(14.0)$ & $39(45.3)$ & $35(40.7)$ & \\
\hline Yes, smoking & $12(16.7)$ & $31(43.1)$ & $29(40.3)$ & \\
\hline Medication use & & & & 0.001 \\
\hline No & $33(23.6)$ & $71(50.7)$ & $36(25.7)$ & \\
\hline Yes & $28(11.9)$ & $92(39.0)$ & $116(49.2)$ & \\
\hline Health care need & & & & 0.001 \\
\hline No & $18(23.7)$ & $41(53.9)$ & $17(22.4)$ & \\
\hline Yes & $39(13.1)$ & $123(41.1)$ & $135(45.5)$ & \\
\hline Psychological counseling & & & & 0.001 \\
\hline No & $49(20.4)$ & $115(47.9)$ & $76(31.7)$ & \\
\hline Yes & $9(6.8)$ & $49(37.1)$ & $74(56.1)$ & \\
\hline Daily sleeping hours & & & & 0.029 \\
\hline $0-4$ & $3(18.8)$ & $5(31.3)$ & $8(50.0)$ & \\
\hline $5-8$ & $53(15.5)$ & $154(45.0)$ & $135(39.5)$ & \\
\hline $9-12$ & $9(39.1)$ & $5(21.7)$ & $9(39.1)$ & \\
\hline Suspicion for alcoholism & & & & 0.002 \\
\hline No & $56(18.6)$ & $129(42.9)$ & $116(38.5)$ & \\
\hline Yes & - & $15(41.7)$ & $21(58.3)$ & \\
\hline
\end{tabular}

Table 3 indicates, according to the chi-square test, that all variables are associated with pain ( $\mathrm{p}<0.05$ ), except smoking. According to the Binomial test, the proportion of agents with strong/unbearable pain who do not do physical activity, use medicine, require medical care and psychological counseling and are suspected for alcoholism ${ }^{(7)}$ is significantly higher than the other groups assessed with pain $(\mathrm{p}<0.05)$.

After adjusting for potential confounders variables, the socio-educational agents with work leave of up to 9 days ( $\mathrm{OR}=2.26,95 \% \mathrm{CI}=1.12-4.58$ ) and those who were off from 10 to 24 days (OR $=4.63,95 \%$ CI 1.39 to 15.44 ) had higher chances of musculoskeletal pain compared to those who did not have to take time off work. Similarly, agents who needed counseling were 2.96 times more likely to have musculoskeletal pain compared to those who did not have such a need (95\% CI = 1.25-7.03).

Regarding sleep, agents sleeping from 5 to 8 hours were 5.95 times more likely to have musculoskeletal pain when compared to those sleeping 9 to 12 hours per day (95\% CI 1.99-17.81). The other variables lost the association. According to the Hosmer-Lemeshow test, the Final Model can explain well what was observed $(\mathrm{p}=0.912)$.

\section{Discussion}

With regard to limitations on the study design (cross-section), there bias of reverse causality, because it is not possible to clearly demonstrate cause-effect. Another limitation has to do with the instrument used for evaluation of musculoskeletal pain, since this evaluates the self-reported intensity and not the body location. This fact made the comparison with other studies difficult. Thus, to make this approach more effective, we suggest the use of longitudinal design and the use of instruments that identify not only the intensity but also the body region affected by musculoskeletal pain in future studies.

The prevalence of musculoskeletal pain reported by socio-educational agents of Socio-Educational Service Centers of Rio Grande do Sul was considera- 
ble. This shows that they perform their work activities in the presence of musculoskeletal symptoms. However, there is a gap in the scientific literature on this subject, which makes it impossible to compare the results with the same working class.

In line with the high percentage of musculoskeletal pain identified among socio-educational agents, prevalence rates of $100.0 \%{ }^{(8)}$ and $91.0 \%{ }^{(9)}$ have been reported in dentists and nursing professionals, respectively. Musculoskeletal pain affects different classes of workers and is considered a health problem responsible for a large rate of absenteeism at work and expenses with employee health ${ }^{(10)}$.

This study showed higher percentage of female agents with strong/unbearable pain. One possible explanation is the double work performed by women and also the higher risk for low back pain among women compared to men ${ }^{(11)}$. What is unanimous is that back pain constitutes the most common example, independent of the worker's sex, affecting 30 to $40 \%$ of adults. Neck and shoulder pain come second in the list, with prevalence of 15 to $20.0 \%{ }^{(12)}$.

Agents who work the day shift had higher percentage of musculoskeletal pain. This may be a reflection of the inherent characteristics of the work in this period, when the demand is greater and activities require more attention and concentration on the part of agents. It is at this time of day that workshops, family visits, transport to audiences and assistance take place. In contrast, at night, the adolescents return to the dorms and end their activities.

Also, the agents that consider the number of workers in the schedule insufficient had higher percentage of strong/unbearable musculoskeletal pain. The inadequate number of employees leads to decreased production at work, causing overload of tasks and consequent musculoskeletal pain in workers, who compromise the activities previously performed ${ }^{(13)}$.

A total of $46.9 \%$ of the agents did not practice physical activity, and reported musculoskeletal pain. This shows that sedentary workers are more likely to feel pain. This is in line with a study conducted among bus drivers, in which $28.0 \%$ were more likely to feel pain because they did not practice physical exercises $^{(14)}$.

It was shown that $45.5 \%$ of agents who need medical care and $56.1 \%$ of those who need psychological care reported feeling strong/unbearable musculoskeletal pain. Agents may seek health monitoring for implications of the daily work with adolescents that affect their health and well-being, requiring adaptability to various situations, such as coercion and threats. In this situation, they may experience loss of self-esteem and occupational and emotional stress, causing musculoskeletal pain and impact on psychological health $^{(15)}$.

It was also seen that high psychological demands at work can influence the musculoskeletal system. In the case of socio-educational agents, this may be a cause of their report of musculoskeletal pain. Psychological demands can generate great tension in the muscles and exacerbate sensitivity to pain, what can further affect the attention to the symptoms as well as their notification ${ }^{(16)}$.

We also found that socio-educational agents showed significant percentage of suspicion for alcoholism. Alcoholism, besides reflecting the social life, appears as a major problem in occupational health, contributing to absenteeism and accidents at work in both public and private organizations ${ }^{(17)}$. It is noteworthy that alcoholism, when associated with the worker's wear, whether physical or mental, may also favor violence at work.

Smoking had no statistically significant influence in this study. However, $40.7 \%$ of the agents who had formerly smoked but stopped reported musculoskeletal pain of strong/unbearable intensity. These findings are expected because smoking causes muscle 
deconditioning due to decreased oxygen supply in the muscles, facilitating the shortening of fibers and causing strained muscle bands that produce pain. However, another study with health workers also found that non-smokers had higher percentage of musculoskeletal pain ${ }^{(18)}$.

The socio-educational agents who had up to 24 days of absence from work, requiring psychological counseling and who had 5-8 daily sleeping hours were more likely to experience musculoskeletal pain. There were no studies in the literature with similar results for a comparison. However, we can make a comparison with the results of a study of workers in the health sector where the prevalence of musculoskeletal disorders was significantly associated with high physical demand at work (PR=1.51, CI95\% 1.38-1.66) and inadequate environmental conditions ( $\mathrm{PR}=1.72$, CI95\% 1.43-2.06), reasonable environmental conditions (OR=1.52, CI95\% 1.25-1.83) and satisfactory environmental conditions ( $\mathrm{PR}=1.28$, CI95\% 1.05-1.54) when compared to the optimal working conditions ${ }^{(18)}$. Generally, these poor conditions can lead workers to illness, absence from work and, in some cases, psychological support.

Regarding the results that showed that the socio-educational agents with less number of sleeping hours have significantly higher proportion of musculoskeletal pain, it is known that there is increased activity of neurons during sleep with release of some hormones and other important neurotransmitters such as serotonin, which modulates pain and promotes the feeling of well-being. In contrast, agents with 9 to 12 daily sleeping hours were those who had the lower percentage of musculoskeletal pain. This data strengthens the fact that longer sleeping times as well as sleep quality are associated with lower pain sensation, tingling and numbness in all body segments except the shoulder ${ }^{(19)}$. However, the number of hours that workers need to sleep varies from individual to individual. Usually, 6 to 8 sleeping hours per night are enough for most people. Thus, researching this correlation is very important because, in addition to the lack of studies, there are sleep-related problems that may be associated or trigger signs or symptoms, including pain.

The results of the present study can help to provide information for planning and implementing measures to promote prevention of health grievances among socio-educational agents, especially musculoskeletal pain. These measures should be planned in conjunction with the occupational health service, with multidisciplinary expertise, including nursing, which plays an essential role in this scenario, whether in the process of health education, health promotion, or in the treatment and rehabilitation of workers. Nurses need to identify problems, and the environmental and working conditions that may affect socio-educational agents and then take actions to prevent these problems.

\section{Conclusion}

We concluded that socio-educational agents had high prevalence of musculoskeletal pain. The associated factors were work leave of up to 24 days, psychological counseling and less than 8 daily sleeping hours. These results reinforce that preventive measures are extremely important in the control of musculoskeletal disorders among the surveyed agents.

\section{Acknowledgements}

To the financial support from the Conselho Nacional de Desenvolvimento Científico e Tecnológico, Case no 479042/2010-1. 


\section{Collaborations}

Greco PBT and Magnago TSBS contributed to the project design, data analysis interpretation and writing of the article. Luz EMF contributed to the writing of the article, relevant critical review of the intellectual content and final approval of the version to be published. Dal Ongaro J, Chagas BP and Dullius AIS contributed to the data analysis and interpretation.

\section{References}

1. Estado do Rio Grande do Sul (BR). Assembleia Legislativa. Gabinete de Consultoria Legislativa. Lei Estadual no 14/474, de 21 de janeiro de 2014. Institui o Plano de empregos, funções e salários e cria os empregos permanentes e os empregos e funções em Comissão da Fundação de Atendimento Socioeducativo do Rio Grande do Sul. Rio Grande do Sul: Diário Oficial do Estado; 2014.

2. Menicucci CG, Carneiro CB. Entre monstros e vítimas: a coerção e a socialização no sistema socioeducativo de Minas Gerais. Serv Soc Soc. 2011; 107(1):535-56.

3. Grando MK, Kirchhof AL, Beck CL, Trindade LL. As cargas de trabalho em um Centro de Apoio SócioEducativo. Online Braz J Nurs [Internet]. 2006 [citado 2011 ago. 17];5(1). Disponível em: http:// www.objnursing.uff.br/index.php/nursing/ article/view/198/47

4. Carugno M, Pesatori AC, Ferrario MM, Ferrari AL, Silva FJ, Martins AC, etal. Physical and psychosocial risk factors for musculoskeletal disorders in Brazilian and Italian nurses. Cad Saúde Pública. 2012; 28(9):1632-42.

5. Jensen MP, Karoly P, Braver S. The measurement of clinical pain intensity: a comparison of six methods. Pain. 1986; 27(1):117-26.
6. Masur J, Monteiro M. Validation of the "CAGE" alcoholism screening test in Brazilian Psychiatry inpatient hospital setting. J Biol Res. 1983; 16(1):215-8.

7. Instituto Brasileiro de Geografia e Estatística. Diretoria de Pesquisas Coordenação de População e Indicadores Sociais Estudos e Pesquisas Informação Demográfica e Socioeconômica. Síntese de Indicadores Sociais e Censo 2010. Rio de Janeiro: IBGE; 2010.

8. Silva HP, Jesus CS. Sintomas osteomusculares em cirurgiões-dentistas da rede pública. Rev AMRIGS. 2013; 57(1):44-8.

9. Magnago TS, Lima AC, Prochnow A, Ceron MD, Tavares JP, Urbanetto JS, et al. Intensity of musculoskeletal pain and (in) ability to work in nursing. Rev Latino-Am Enfermagem. 2012; 20(6):1125-33.

10. Leon EB, Almeida AR. Academicvs. Rev Cient Neg Tecnol. 2011; 2(1):1-7.

11. Ferreira GD, Silva MC, Rombaldi AJ, Wrege ED, Siqueira FV, Hallal PC. Prevalência de dor nas costas e fatores associados em adultos do Sul do Brasil: estudo de base populacional. Rev Bras Fisioter. 2011;15(1):31-6.

12. Ministério da Previdência Social (BR). Política Nacional de Segurança e Saúde do Trabalhador. Brasília: Ministério da Previdência Social; 2012.

13. Rodrigues BC, Moreira CC, Triana TA, Rabelo JF, Higarashi IH. Limitations and consequences caused by work - related diseases in the worker's lives. Rev Rene. 2013; 14(2):448-57.

14. De Vitta A, Conti MH, Trize DM, Quintino NM, Palma R, Simeão SF. Sintomas musculoesqueléticos em motoristas de ônibus: prevalência e fatores associados Fisioter Mov. 2013; 26(4):863-71.

15. Mascarenhas $\mathrm{CH}$, Prado FO, Fernandes MH. Fatores associados à qualidade de vida de Agentes Comunitários de Saúde. Ciênc Saúde Coletiva. 2013; 18(5):1375-86. 
16. Fonseca NR, Fernandes RC. Factors related to musculoskeletal disorders in nursing workers. Rev Latino-Am Enfermagem. 2010; 18(6):107683.

17. Machado EC. Alcoolismo no trabalho: Uma visão da equipe de enfermagem. Rev Saúde Desenvolvimento. 2014; 6(3):202-18.
18. Barbosa RE, Assunção AA, Araújo TM. Distúrbios musculoesqueléticos em trabalhadores do setor saúde de Belo Horizonte, Minas Gerais, Brasil. Cad Saúde Pública. 2012; 28(8):1569-80.

19. Bleyer FT, Barbosa DG, Andrade RD, Teixeira CS, Felden EP. Sono e queixas musculoesquéticas de atletas de elite catarinenses. Rev Dor. 2015; 16(2):102-8. 